\title{
Terrorist Strategy And Global Economic Implications
}

\author{
Michael Cosgrove, (E-mail: mcos@gsm.udallas.edu), University of Dallas
}

\begin{abstract}
This paper attempts to show that Al Qaeda leaders follow a basic model of utility maximization constrained by their available resources. Their resource constraints led to what appears to be a relatively flat transnational organizational model design in an attempt to challenge the U.S. military pyramid and free market American system. It is suggested that the 911 attacks were meant to serve as a catalyst to induce the U.S. to respond in a manner that might move the terrorists closer to their objectives. That may not have occurred but the 911 attacks were cost effective in creating large dollar costs on the U.S. and global economy. The direct costs of the attacks for the U.S. were much less important than the cumulative costs accruing to the U.S. and global economy from, in part, the post 911 U.S. response to the attacks.
\end{abstract}

Longer run expected economic costs of 911 attacks range from increased private and public sector expenditures, a slowing of growth in global trade, to expected adverse effects on potential output and increased volatility of business cycles. The U.S. response to terrorist activity in terms of increased outlays and tighter security measures appears to be based on the assumption that terrorists may plan to use weapons of mass destruction at some point and/or the U.S. is extrapolating an annual terrorist event of a magnitude equivalent to the 911 casualties and costs. Otherwise, historical civilian casualty numbers resulting from terrorist actions over the past several decades may not warrant this sizeable U.S. response. But U.S. consumers and taxpayers seem willing to pay higher costs to reduce the threat of terrorist attacks in the U.S. Other countries, in comparison, seem to rely more on historical civilian casualties in formulating their response. Of course, free-rider benefits do accrue to our Allies from U.S. military actions abroad.

\subsection{Strategy}

P erhaps the key lesson that Saddam Hussein and others around the world learned from Iraq's crushing defeat in the 1991 Gulf War was to not attempt a symmetrical war against the U.S. Opposition forces learned that the U.S. could not be challenged on a symmetrical basis and turned to basic business concepts such as strategic organization for methods to address America's overpowering military advantage. In other words, they learned that head-to-head competition would fail.

The U.S. is the dominant military force in the world, but in response to acts of 19 hijackers on 911 the U.S. is spending billions more attempting to eradicate global terrorists and build a more dependable domestic defense system. America's global military and domestic security responses to the 911 attacks are part of large pyramid Federal government bureaucracies. In comparison the 19 hijackers appear to have been part of a loosely organized al Qaeda force whose membership is alleged to run in the thousands. Leaders of al Qaeda knew they could not defeat the U.S., but probably hoped to gain a psychological warfare victory in the attack and perhaps the U.S. response to their terrorist action would serve as a catalyst for achieving some of their objectives. Terrorism is the application of violence or threatened violence that is intended to create panic and fear in society and eventually bring about political change in the country attacked (Laqueur, 1996, page 24.)

$\overline{\text { Readers with comments }}$ or questions are encouraged to contact the author via email. 


\subsection{Business Model}

Two aspects of terrorist groups and in particular al Qaeda seem to involve basic business concepts. One is that al Qaeda leaders appear to be maximizing a utility function that is constrained by factors such as financing and other resources. Al Qaeda leaders have made public statements that imply terrorist utility would be enhanced by achievement of items such as removal of the U.S. presence from Saudi Arabia and other Islamic nations and a return of Israeli occupied lands. Left unstated is that terrorist leaders may also relish the aspects of power and fame that accompany their actions. In this sense terrorist group leaders may satisfy aspects of both the self-interest and present-aim rationality standards. Terrorist leaders by their actions are making public choices.

Constraints that limit movement toward optimum al Qaeda utility levels are many and encompass the spectrum of military equipment and supplies, manpower, training and financial resources. Terrorist leaders apparently understood the limitations and asked themselves how they could move toward their objectives with very limited resources. Terrorists must have worked on the premise that after any attack the U.S. military would be unleashed on any pyramid structure they had and that command and control system would be demolished just like occurred with Saddam's command and control system in 1991. Terrorist leaders must have asked themselves how they could maintain some command and control over their membership after U.S. retaliation.

The U.S. Air Force asked themselves a somewhat similar question in the early 1960s - how could the Air Force maintain its command and control over its bombers and missiles after a nuclear attack? Individuals at RAND developed an answer for the U.S. military. Design a network with no central authority so it would continue to operate while in shambles. The RAND design was built on the premise of an unreliable network, as segments would be destroyed. So each node in the network would be equal in status to all other nodes. Each node would have its own ability to receive, send and originate messages. Messages would be divided into packets with each packet winding its way through the network on an individual basis. This delivery system was inefficient in its design but durable. The Rand concept and work by other entities such as MIT eventually evolved into the Internet.

The RAND-type command-and-control network concept, first envisioned as a defensive communications network, was turned into an offensive strategic weapon by terrorists to asymmetrically challenge the U.S. military pyramid and our American system. Terrorists knew the U.S. would take out any complex command and control system, so they designed a strategy around the Internet concept of transnational nodes with communication among nodes occurring by all methods including the Internet. Terrorists face a dominant pyramid based military power and decided to directly compete with the U.S. using a relatively flat organizational concept.

We have been told terrorist cells are scattered across the globe, perhaps in as many as 50 countries with as many as 20,000 recruits from more than 20 countries. Terrorists trained in the tactics of terrorism graduated from a dozen or so training camps in Afghanistan. Mr. bin Laden established his base of operations in Afghanistan in 1996 according to Rohde and Chivers (2002) and appears to have taken advantage of network externalities on the supply side by crossing national borders. The al Qaeda idea may also have been that the fame for members resulting from 911 might effectively shift both demand and the supply of recruits to the right for the various cells in the different countries that al Qaeda allegedly operates in.

The al Qaeda terrorist organization basically adopted a decentralized organizational concept - the opposite of the U.S. military machine. Al Qaeda seems to fall into the virtual internet transnational corporate concept where individuals or teams band together to form self-directed teams or cells within a loose or virtual organization. Individuals must be empowered within each team or cell to add and remove team members. Independent cells allow for specialization and division of labor as members with specific skill sets can be combined. A huge advantage to al Qaeda of this flat organization is that it makes a very difficult target for the U.S. military to destroy. Plus lack of a pyramid concept in al Qaeda means that it eliminates the need individuals might feel to move higher within the organization ranks. However, authority on when and what to attack is perhaps held at the top by a few people. Each cell is probably empowered to carry out activities to promote viability of the cell but the decision involving an attack likely rests entirely with a few people who were or are close to bin Laden. 
Disadvantages of this flat type of organization include lack of control, training, discipline and access to financing. Al Qaeda is dispersed and its membership involves people from different countries and backgrounds. Small cells provide what are essentially self-directed teams but these teams can't provide the training, discipline and competency that a well funded pyramid organization can. Plus the incentive of smaller cells to carry out terrorist attacks may dissipate as nodes in the network are destroyed and as funding sources become less generous. Defections may increase and cells may dissipate without adequate funding and well defined command and control systems.

The apparent type of al Qaeda organization suggests they expected a retaliatory attack by the U.S. military in Afghanistan. It is not clear that al Qaeda leaders expected the massive U.S. and Allied response. There may have been an expectation on the part of terrorists of more limited attacks as occurred after the prior attacks such as the bombing of the World Trade Towers, destruction of the Al Khubar Towers, attack on U.S. embassies and bombing of the USS Cole.

\subsection{Differences}

Application of business concepts to terrorist entities ends with utility maximization and organization. Political terrorists have a unique evil strategy in that they expect to move toward their desired end, not directly by their attack, but indirectly by the response to the act itself. The idea is that the attack acts as catalyst to move the country that was attacked toward a position desired by the terrorist. Violence is the direct effect but consequences and responses to the violent acts by the target country are the actions that might move the target toward an end that is desired by terrorists. The direct effect - violence creates fear and anger - that fear then generates a response to the direct effect and that response may lead to an objective that the political terrorist group hoped to achieve (Fromkin, 1975, page 693.)

Implementation of this strategy means that terrorist groups attack civilian targets in order to maximize fear and anger and hopefully create some change in the entity attacked. The evil attack(s) may seem pointless but that is the purpose. The attack of civilian targets such as the World Trade Center Towers - apparent symbols of U.S. financial domination of the world's economic system -- creates fear and anger that terrorist groups hope will cause the U.S. to respond in a way that creates large economic costs and loss of liberties within the U.S. And if so, it makes the initial terrorist attack very cost effective.

\subsection{U.S. And Global Responses}

The potential price of committing terrorist acts has incrementally risen for terrorists as the U.S. attempts to deter further terrorist attacks. Steps that increased the effective price of any terrorist action include U.S. military efforts abroad to find and destroy terrorist cells and a plethora of internal actions including a Department of Homeland Security that will coordinate activities from border security to processing intelligence reports from different agencies. Political terrorist leaders and their followers may factor this increased cost into their calculation of expected net benefits of terrorism. These actions seem to imply that the likelihood of future attacks should be reduced as long as expected net benefits from terrorist activities in the U.S. have been reduced. However net benefits accruing to terrorist groups due to 911 attacks may have vastly exceeded expected benefits. If so, the U.S. and Allied response in Afghanistan and homeland security measures may have little impact on terrorist decision making in the short run. Over time, the U.S. and Allied responses may work to reduce expected net benefits of terrorist acts.

Greater U.S. homeland security implies that terrorists have choices to make when facing a greater deterrent. Incur smaller net benefits if their decision is to attack the U.S., or substitute targets in other countries where the likelihood of resistance is lower. The implication is that effective U.S. homeland security measures substitute the increased probability of attacks in less well defended countries. Governments of other countries, knowing this, can make a choice on allocation of monies and increase their homeland defense. Efforts of other governments to increase their homeland security and efforts to share and coordinate intelligence among countries may act as a deterrent. However, increased U.S. military and security efforts as a percent of GDP are larger than efforts of other 
countries, and if terrorists were indifferent with respect to target countries, other countries could expect an increased likelihood of attack.

At the same time it appears to be a rational response on the part of other countries to allocate smaller amounts as a proportion of their respective GDP on increased security. The number of deaths and wounded in all global geographic areas from international terrorist events averaged 325/year and 1172/year from1970 to 2000 (U.S. Department of State (2002) and (Sandler and Enders, 2002). Events of 911 created a huge spike in civilian casualties from terrorism but many decision makers may perceive the 2001 event as an outlier. Other countries that use data on civilian casualties resulting from transnational terrorism over the last three decades could be making a rational decision in their moderate response. Historical numbers of civilian dead and wounded from terrorist attacks do not appear to justify increased security outlays to reduce risks from a cost-benefit perspective.

U.S. civilian deaths from transnational terrorist attacks averaged 10/year from 1991 to 2000. It is perhaps difficult to make the case that the U.S. should have stepped up outlays on intelligence and domestic security outlays in response to this number of deaths. In comparison the number of U.S. highway fatalities averaged 41,800 annually from 1995 to 1999. U.S. citizens learned to accept risks inherent in driving an auto but seem to be less willing to accept risks associated with transnational terrorism. Citizens are willing to support increased public and private sector direct security costs as well as opportunity costs of additional wait times at airports and make changes in lifestyles in an attempt to reduce what has been over the past three decades a relatively small risk of dying from transnational terrorism attacks.

It seems to be understandable that leaders of other countries, at least initially, lacked the zeal of U.S. leaders in increasing security outlays. In addition, al Qaeda leaders, as demonstrated by 911 attacks, have a preference for attacking U.S. targets in the U.S. In the end the deterrent effect of increased security measures in the U.S., to be effective, needs to be processed by terrorist leaders and that may take some time. Terrorists operated for decades without a major U.S. response. It wasn't until the 2001 terrorist attack that the U.S. made a major response. The car bombing of the World Trade Center Towers, destruction of Al Khubar Towers, attacks on U.S. embassies and bombing of the USS Cole failed to initiate a large U.S. response. But the terrorist choice of organization styles implies that they had expected retaliatory attacks.

The U.S. has and is responding to the 911 attacks and is making it more costly for terrorist entities to attack the U.S. Terrorist entities could attempt to counter such moves through use of weapons of mass destruction to increase their perceived benefits. Terrorists could perceive that the use of WMD might be a catalyst to create a drastic change within the U.S. and move the terrorists closer to their objectives.

Deterrence is perhaps most achievable when the terrorism is state-sponsored as the leaders of the state probably understand the threat of a second-strike retaliation. Retaliation however requires knowledge of who launched the attack and their location (Betts, 1998, p. 34.) Threat of annihilation provides a major constraint. That constraint is missing when discussing anonymous terrorists and suicide operatives. As a result the U.S. seems to be moving toward preemptive strikes on known terrorist groups along with tighter domestic security. Effects on potential loss of liberties may become clear in the years ahead while some of the economic costs on the U.S. and global economy are emerging. The magnitude of economic costs seems to clearly illustrate that al Qaeda, from their perspective, launched a very cost effective attack on the World Trade Center.

\subsection{Economic Impacts}

Impacts of prior policies such as the Federal Reserve decision to tighten monetary policy in 2001 and posty2k effects turned real GDP growth negative in the first three quarters of 2001 Short term incremental negative impacts of 911 added to downward GDP pressure in the third quarter and were severe, in particular in the airline, hotel/tourism, insurance and advertising sectors. Direct losses from the 911 attack have been estimated at approximately $\$ 70$ billion which includes destroyed public and private property and lost output in the immediate aftermath (Zandi, 2002). Cumulative losses including lower corporate profits, higher discount rates for economic volatility and loss in stock market wealth could approach $\$ 2$ trillion (Navarro and Spencer, 2001). That $\$ 2$ trillion 
may be on the low side for a longer term cumulative loss while another source puts the U.S. short term cumulative GDP loss at half a trillion dollars (OECD, 2002, p. 119). If portions of equity market declines in 2002 are attributed to after-shocks of events of 911, the cumulative loss could easily exceed the \$2 trillion. In comparison the al Qaeda cost of the attack on the World Trade Center was in the millions.

A substantial portion of cumulative U.S. and global costs may be a result of the U.S. response to the terrorist attacks. It is the cumulative costs and impacts on the U.S. that perhaps the terrorists hoped would somehow result in movement toward the terrorist objectives. The 911 attack was designed to be the catalyst to produce a much larger adverse cost on the U.S. that the U.S. would create by its response to the 911 attacks. But the American public seems to perceive that the cumulative costs are worth it if it substantially lessens the threat of terrorist attacks in the U.S.

Preliminary numbers show that real GDP growth turned positive in the fourth quarter as the economy started to recover from short-term adverse impacts, Figure 1.

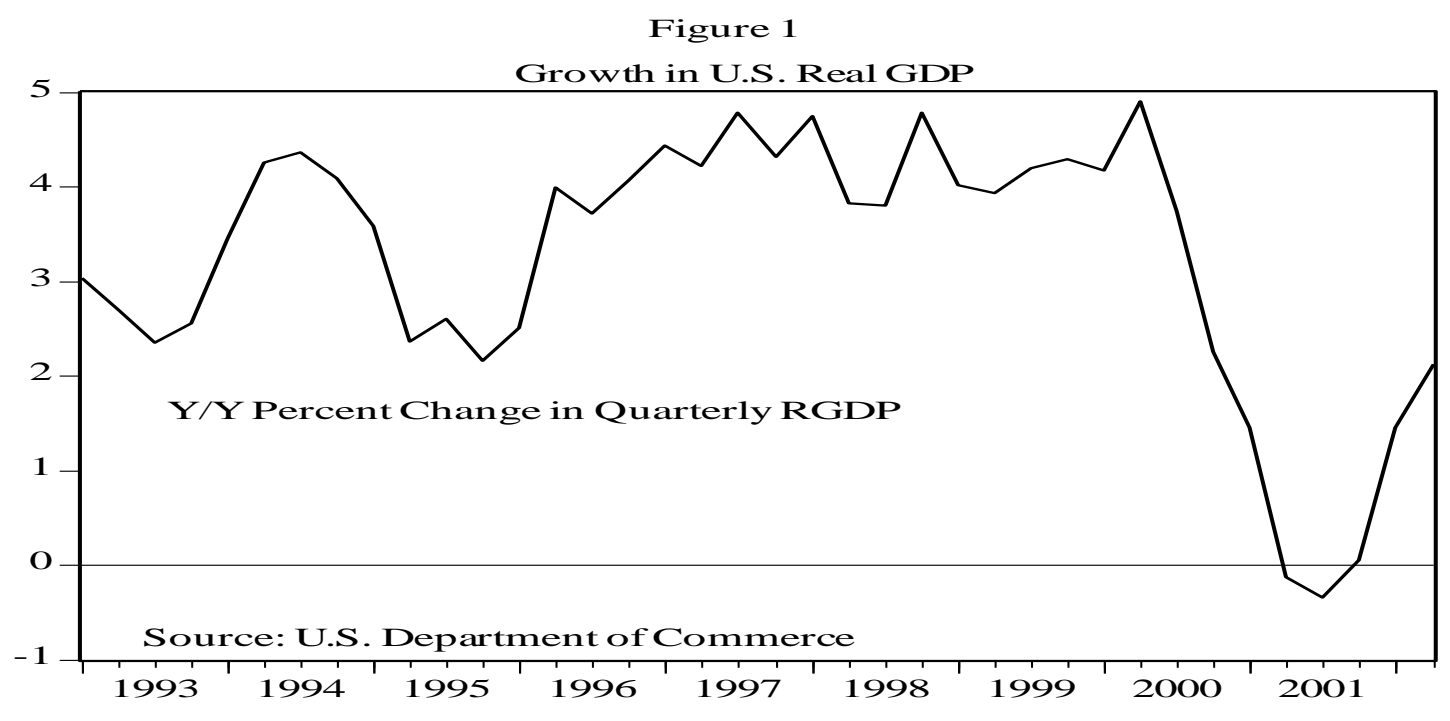

Terrorist acts of 911 set in motion a chain of events that may reduce potential GDP growth for much of this decade without positive offsetting shocks. Adverse impacts to the real economy are occurring through various channels including trade and loss of the peace dividend.

U.S. border security measures tightened drastically after 911 but appear to have relaxed somewhat since then. But the net effect is that cross-border U.S. mobility has been reduced. Some slowdown in mobility could also have occurred across country borders in other geographic areas. This reduced mobility, at least in the U.S., appears to adversely impact immigration, net portfolio capital flows, net flows of goods and services and perhaps FDI.

Labor mobility is reduced to the extent increased U.S. border security measures slow issuance of both work and student visas as well as illegal immigration. The slowdown in issuance of visas adversely affected the supply of students able to consume U.S. educational services, and those students who do obtain visas may have more difficulty remaining in the U.S. once their education is completed. Opportunity costs of longer waits to enter the U.S. for education and a reduced likelihood of remaining in the U.S. upon completion of their education implies that at the margin both the U.S. and global labor force are adversely impacted. Educational opportunities provided via the Internet may offset some of the supply disruption but the impact on potential growth is a negative to the extent that labor mobility for an educated work force is reduced. 
Tighter border controls on issuance of work visas may impact growth of the foreign-born labor force which comprises 13 percent or 18.4 million of the U.S. labor force. In 1970 that proportion was 5 percent. It is estimated nearly eight million out of the 18.4 million are in skilled positions (Epstein, 2002).

A slowing in issuance of work visas and reduction in the entrance of illegal immigrants suggests potential upward U.S. labor cost pressures as the economy resumes its growth. U.S. borders have been very porous. The cost of entering the U.S. increased after 911 and Congress and the Administration have a large bureaucracy in place to further tighten U.S. borders should the need occur.

\subsection{Net Foreign Financial Portfolio Flows}

Investors have a substantial home bias and while the degree of home bias decreased in the past 20 years it remains high. Higher transaction costs do not appear to be a factor in that home bias (Warnock, 2001, page 1.) This bias existed before terrorist attacks of 911 and after 911 it would appear that investors would have an increased preference for investing in their own country. Does an investor in Japan want monies locked in the U.S. capital markets should U.S. financial markets be shutdown for a period of time? Or does a U.S. investor want monies held in foreign capital markets if an attack in London shuts down that exchange for a period of time? Investors may perceive expectations for reduced global growth due to 911 security impacts and allocate investment monies away from liquid markets. Preliminary numbers suggest that a slowing in growth of net flows to the U.S. is underway. A gradual slowing was underway before 911 but a further slowing occurred, Tables 1 and 2 .

Table 1

Foreign Balances in U.S. Financial Markets

(Billions of dollars) (end of period)

$\begin{array}{lrrrrrr} & \mathbf{2 0 0 2 : Q 2} & \mathbf{2 0 0 1} & \mathbf{2 0 0 0} & \mathbf{1 9 9 9} & \mathbf{1 9 9 8} & \mathbf{1 9 9 7} \\ \text { Total Balance } & & & & & & \\ & \$ 7,170 & 6,960 & 6,516 & 5,800 & 5,200 & 4,627 \\ \text { Credit Markets } & 3139 & 2,954 & 2,621 & 2,355 & 2,278 & 2,098 \\ \text { Equities } & 1418 & 1,534 & 1625 & 1612 & 1250 & 953 \\ \text { FDI } & 1518 & 1,499 & 1375 & 1101 & 920 & 824 \\ \text { Other } & 1095 & 973 & 895 & 732 & 752 & 752\end{array}$

Source: Federal Reserve Flow of Funds

\subsection{Foreign Direct Investment}

Growth in FDI is slowing in conjunction with the slowing of U.S. cross-border labor and financial portfolio capital flows and flows of goods. Preferences by entities from other countries for large direct investments in the U.S. may be reduced after 911 events if foreigners contemplating FDI in the U.S. decide to shift those investment dollars to countries they perceive as less likely to incur terrorist attacks. On the other hand, foreigners could have an increased propensity for FDI in the U.S. due to the uncertainty and increased cost of shipping goods into the U.S. and create an increased preference for U.S. FDI. 
Table 2

\section{Percentage Change in Foreign Balances}

$\begin{array}{lccccc} & \mathbf{2 0 0 2 : Q 2} & \mathbf{2 0 0 1} & \mathbf{2 0 0 0} & \mathbf{1 9 9 9} & \mathbf{1 9 9 8} \\ & & & & & \\ \text { Total Balance } & 3.8^{*} & 6.8^{* *} & 12.3 & 11.5 & 12.4 \\ & & & & & \\ \quad \text { Non FDI Sector } & 4.0 & 6.2 & 9.4 & 9.8 & 12.5 \\ \quad \text { FDI } & 3.1 & 9.0 & 24.9 & 19.7 & 11.7 \\ & & & & & \\ *=2002: \mathrm{Q} 2 / 2001: \mathrm{Q} 2 & & & & & \\ * *=\text { year end/year end } & & & & \end{array}$

Source: Federal Reserve Flow of Funds

\subsection{Trade Flows}

Growth in flows of goods is likely to moderate due to 911 impacts. Companies that relied on just-in-time inventory management suffered shortages just after 911 , as waiting time increased for trucks at borders and as the cost of transportation increased by both air and sea. Tighter security measures have been proposed; one proposal is to implement security measures on shipment of containers. Select major ports of origin that ship to the U.S. are participating in stricter security measures as part of a cooperative Customs-Trade Partnership Against Terrorism program aimed at heightening security in the supply chain. It is estimated that roughly 90 percent of the world's cargo moves via containers and the U.S. processed 5.7 million containers in 2001 (U.S. Customs, 2002). Increased security of containers likely means both higher capital and variable costs. Development of new technology may work to speed the delivery wait time so that efficiency of the supply chain eventually returns toward normal. But companies may pay higher out of pocket costs plus incur longer delivery times. Some of those costs will be passed through to customers in the form of higher product prices. Taxpayers, of course, pay for the additional public sector costs.

It has been estimated that post 911 security measures could increase global logistical and administrative trading costs within a range of between $1 \%$ and 3\% of the value of the goods involved (Leonard, 2001). Costs of imports and exports are very sensitive to tighter border security measures, and Canadian and Mexican borders are very important to the U.S. machinery and transportation sectors. Limao and Venables (2001) estimate a price elasticity of approximately a negative 3 with respect to the trade cost factor. Application of this elasticity to higher trade costs suggests that the post 911 terrorism impacts would be a major negative and lead to a meaningful slowing in international trade with negative adverse effects on U.S. productivity and growth (OECD, p. 132). The U.S. runs a sizeable trade deficit and tighter border security would increase costs of U.S. exports and unless offset by a proportional slowing in imports may worsen this country's trade deficit.

The home bias that exists in foreign financial portfolio flows doesn't appear to exist between foreign and domestic goods (Evans, 2001, page 19.) The apparent home bias against imports fades once differences in incremental costs of imports due to transportation and tariffs are adjusted for. But the effect of terrorist activity is to increase incremental costs in the global supply chain. In particular, security concerns that act to increase costs and slow efficiency of the global supply chain are likely to have a disproportionate adverse impact on imports and exports and therefore economic output of more open economies. Since the U.S. is less open than major European markets, equal application of security measures across countries would suggest that the U.S. would be impacted less adversely. But the application of security measures is very unequal with the U.S. leading in increased securityrelated budgetary spending (OECD, 134). Canada and the United Kingdom among OECD countries are expected to increase their outlays as a percent of GDP more closely to that of the U.S. 
Adverse impacts of terrorist attacks on emerging market economies may be more severe than on developed countries. Emerging market economies tend to export more commodities and perishable goods that have higher transportation costs. Additional security at borders of developed countries implies slower growth in volume of exports from emerging market economies due to higher transportation costs which would mean an erosion of their competitive position.

Supply chain impacts of increased border security may have a major impact on just in time companies, as they may need to alter their inventory practices. Improved supply chain management allowed companies to conduct business by carrying smaller inventories and reducing costs. It is estimated that movement back to the 1990 inventory levels could add an annual inventory carrying cost of 0.7 percent of GDP (OECD, p. 130). Additional terrorist attacks could also add a precautionary element to inventory stocking, in particular by those segments of the economy that only carry one or two or a few days of inventory.

\subsection{Public And Private Sector Security Outlays}

The U.S. enjoyed the peace dividend in the latter part of the 1980s and the 1990s, Figure 2. National defense spending decreased from nearly $7.5 \%$ in 1986 to approximately $4 \%$ in 2001 . Public sector spending for the U.S. military and related domestic terrorism defense could easily increase this relationship to 5 percent or more from the nearly 4 percent in 2001 depending on how the domestic security portion of national defense is estimated. This increase does not include the incremental costs of military action in the Middle East. The 1991 Persian Gulf War cost an estimated incremental $\$ 60$ billion with much of that paid for by our Allies. That $\$ 60$ billion is approximately $\$ 80$ billion in today's dollars which does not include occupation costs.

Positive externalities of U.S. military actions in the campaign against terrorism accrue to our Allies. Likewise if the U.S. does remove Saddam Hussein, our Allies receive the positive spillovers and become free riders. Causalities from terrorism over the past three decades imply that attempts by other countries to be free riders may be reasonable. The implication is that the U.S. taxpayer would pay a much higher percentage of a Middle East conflict compared to the 1991 Persian Gulf War. U.S. taxpayers may also bear most of the rebuilding costs in the Middle East. A growth Federal deficit that might lead to higher interest rates and/or increased tax rates would have an adverse impact on the U.S. and global economy.

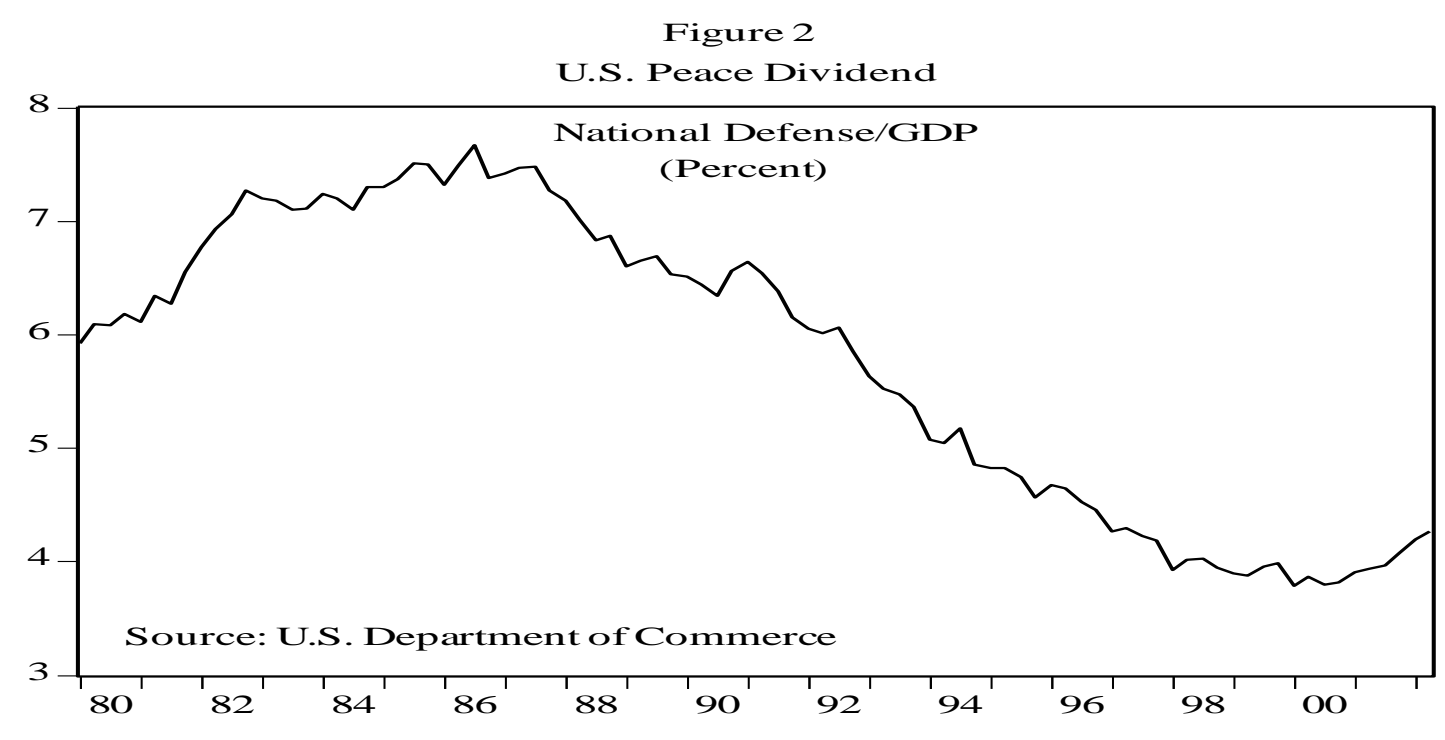

Globally it was estimated that military spending fell to 2.4 percent of global GDP in 1995 from 3.6 percent in 1990. This decline occurred in developed economies as well as in transitional economies and was widespread, 
occurring in 90 of the 130 countries in the study (Clements el al., 1997.) The longer-term impact of increased defense spending on potential growth is questionable but increased defense spending does seem to have adverse impacts on potential output.

Private sector security in developed countries was expected to sharply increase in areas such as security guards, skilled positions and technology. Business had been expected to implement additional security measures after 911 attacks in terms of both unskilled and skilled positions and to upgrade security measures for their communication and information systems. There has been some increase but the private sector security spending increase does not appear to be nearly as major as had been expected. Business insurance cost increases have been substantial, however.

\subsection{Cumulative Impacts}

One source estimated that the combination of possible increased U.S. public and private sector security spending would reduce U.S. output by nearly $0.7 \%$ after five years, while in the short run, aggregate demand would be positively impacted (OECD, p. 136). That adverse impact is perhaps overstated as private sector increased security spending appears to be less than expected. Increased security efforts by other countries have not been of the same relative magnitude as in the U.S. and therefore the potential longer run adverse impact on GDP of other countries would likely be less. The uncertainty created by 911 attacks in the global financial and economic systems could also work to alter the expected length of U.S. business cycles. A reduction in output of $0.7 \%$ after five years, should that occur, means that potential growth would be lower than otherwise and therefore the risk of an external shock pushing U.S. economic growth negative would be increased.

The current Federal Reserve Chairman, Mr. Greenspan (2002) noted that there had been a "... reduction in volatility of output and in the frequency and amplitude of business cycles for the macroeconomy." That observed recent volatility reduction likely reflected improvements in technology that provided timely signals to firms in helping to prevent major imbalances from occurring and, in the aggregate, help stabilize the economy. A return to mean business cycle volatility may occur if potential output growth slows in the U.S. due to the post 911 effects. A slowing of potential output in conjunction with occasional spikes in global terrorist activity and concerns along with cyclical variations in commodity prices and interest rates could lead to increased volatility in output.

\subsection{Summary}

The objective of terrorism is to create that initial fear and anger which serves as a catalyst to hopefully induce the U.S. to respond in a method that might move the U.S. toward an objective that the terrorists hoped for. The U.S. post 911 responses appear to have created adverse effects over time on potential GDP through the supply chain, military channel, capital flow channel and increased cost of private and public sector domestic security. It appears that the 911 terrorist attack was very cost effective from the terrorist perspective as their direct cost outlay was perhaps in the millions. U.S. direct costs of the 911 attack in terms of destroyed property and lost output in the immediate few days after the attack have been estimated at approximately $\$ 70$ billion while cumulative losses have been estimated at $\$ 2$ trillion and perhaps more.

However the U.S. response in Afghanistan was probably much more devastating than what terrorists had expected. Terrorists, by their adoption of a horizontal organization style, probably expected an attack, just not the magnitude of attack that occurred. Loss of al Qaeda leaders, if that occurred, was probably unexpected. The magnitude of the U.S. response abroad and at home increased the cost to terrorists of additional attacks. But actual and perceived net benefits to the terrorists of 911 were probably so large that the additional costs of terrorist attacks won't be prohibitive. Terrorists might eventually counter an increased cost through use of WMD as a method to increase their potential benefits. Actions of U.S. leaders suggest that they are concerned about possible use of WMD by terrorists and/or are using 911 casualties and are extrapolating an annual attack of that magnitude into the future. The American public seems to support many or most U.S. actions that contribute to the large cumulative losses so they implicitly agree with one or both premises on which U.S. actions appear to be based. U.S. consumers and taxpayers are apparently willing to pay substantially higher costs to reduce the threat of terrorist attacks in the U.S. 
Allies, in comparison, seem to be relying more on data of civilian casualties over the last three decades that resulted from transnational terrorist actions in formulating their public policy. Plus Allies enjoy free rider benefits from U.S. military actions abroad that are U.S. taxpayer supported.

\section{U.S. Business Cycle Expansions and Recessions}

\begin{tabular}{|c|c|c|c|}
\hline Trough & Peak & $\begin{array}{c}\begin{array}{c}\text { Expansion } \\
\text { Trough to Peak }\end{array} \\
\text { Months }\end{array}$ & $\begin{array}{c}\text { Recession } \\
\text { Trough from } \\
\text { prior peak }\end{array}$ \\
\hline Mar. 1919 & Jan. 1920 & 10 & 7 \\
\hline July 1921 & May 1923 & 22 & 18 \\
\hline July 1924 & Oct. 1926 & 27 & 14 \\
\hline Nov. 1927 & Aug. 1929 & 21 & 13 \\
\hline Mar. 1933 & May 1937 & 50 & 43 \\
\hline Jun. 1938 & Feb. 1945 & 80 & 13 \\
\hline Oct. 1945 & Nov. 1948 & 37 & 8 \\
\hline Oct. 1949 & July 1953 & 45 & 11 \\
\hline May 1954 & Aug.1957 & 39 & 10 \\
\hline Ap. 1958 & Ap. 1960 & 24 & 8 \\
\hline Feb. 1961 & Dec. 1969 & 106 & 10 \\
\hline Nov. 1970 & Nov. 1973 & 36 & 11 \\
\hline Mar. 1975 & Jan. 1980 & 58 & 16 \\
\hline July 1980 & July 1981 & 12 & 6 \\
\hline Nov. 1982 & July 1990 & 92 & 16 \\
\hline Mar. 1991 & Mar. 2001 & 120 & 8 \\
\hline \multicolumn{2}{|c|}{ Average } & 49 & 13 \\
\hline
\end{tabular}

Source: National Bureau of Economic Research

\section{References}

1. $\quad$ Bretts, Richard K. (1998). "The New Threat of Mass Destruction." Foreign Affairs, Volume 77, (1), 26-41.

2. Clements, B., Gupta, S., and Schiff, J. (1997). "What Happened to the Peace Dividend?" International Monetary Fund, Finance \& Development, Volume 34, (1), 17-19.

3. $\quad$ Epstein, Gene. (2002). "New Melting Pot." Barron's, September 2, 2002.

4. $\quad$ Evans, Carolyn L. (2001). "Home Bias in Trade: Location or Foreign-ness?" Federal Reserve Bank of New York, Staff Reports, May, Number 128.

5. "Flow of Funds Accounts of the United States" (2002), Board of Governors of the Federal Reserve System, Washington, DC, June.

6. $\quad$ Fromkin, David. (1975). "The Strategy of Terrorism.” Foreign Affairs, Volume 53, (4), 683-698.

7. Laqueur, Walter. (1996). "Postmodern Terrorism." Foreign Affairs, Volume 75, (5), 24-36.

8. Leonard, Jeremy A. (2001). "Impact of the September 11, 2001 Terrorist Attacks on North American Trade Flows." Manufacturers Alliance/MAPI e-Alert, October, Arlington, Virginia. 
9. Limao, Nuno and Venables, Anthony J. (2001). "Infrastructure, Geographical Disadvantage, Transport Costs, and Trade." The World Bank Economic Review, Volume 15, (3), 451-497.

10. Navarro, Peter and Spencer, Aron. (2001). "Assessing the Costs of Terrorism." The Milken Institute Review, Fourth Quarter, 17 -31.

11. OECD (2002). "Economic Consequences of Terrorism." OECD Economic Outlook No 71, Chapter 4.

12. Rohde, David and Chivers, C. J. (2002). "Al Qaeda's Grocery Lists and Manuals of Killing." New York Times, March 17, 2002.

13. Sandler, Todd and Enders, Walter. (2002). An Economic Perspective on Transnational Terrorism, February 2002. Unpublished manuscript.

14. U.S. Customs (2002). "U.S. Customs Container Security Initiative Forging Ahead." Office of Public Affairs, Washington, August 8.

15. U.S. Department of State (2002). "Patterns of Global Terrorism." Bureau of Public Affairs, May.

16. Warnock, Francis E. (2001). "Home Bias and High turnover Reconsidered." Board of Governors of the Federal Reserve System, International Finance Discussion Paper \# 702, December.

17. Zandi, Mark. (2002). “9/11’s Economic Fallout," 9/9/02, Economy.com

Notes 
Notes 